Bangladesh J. Sci. Ind. Res. 42(3), 327-334, 2007

\title{
Transfer of Cadmium from Soil to Vegetable Crops
}

\author{
M. Z. Hossain, ${ }^{\text {a }}$ S. M. Ullah, ${ }^{\text {b }}$ S. A. Ahad ${ }^{b}$ and M. B. Ullah ${ }^{b}$ \\ ${ }^{a}$ Soil Science Discipline, Khulna University, Khulna-9208, Bangladesh. \\ ${ }^{b}$ Department of Soil, Water and Environment, Dhaka University, \\ Dhaka-1000, Bangladesh
}

\begin{abstract}
A pot experiment was conducted in order to study the transfer of $\mathrm{Cd}$ from soil to the vegetable crops namely Lettuce (Lactuca sativa L.), Spinach (Spinacia oleracea L.), Lal sak (Amaranthus tricolor L.) and Data sak (Amaranthus spinosis L.). The mean transfer factors (concentration in plant dry weight / concentration in soil dry weight) varied from 2.030 to 6.785 in root and 0.166 to 0.525 in shoot. The following mean Cd-transfer factors (DW/DW) were obtained; Lettuce (root: 6.785, shoot: 0.271), Spinach (root: 4.775, shoot: 0.385), Lal sak (root: 2.03, shoot: 0.166) and Data sak (root: 3.445, shoot: 0.525 ). The transfer factor of $\mathrm{Cd}$ in roots of vegetables decreased in the order: Lettuce $>$ Spinach $>$ Data sak $>$ Lal sak; while in shoots it was Data sak $>$ Spinach $>$ Lettuce $>$ Lal sak.
\end{abstract}

Key words : Cadmium, transfer, soil and vegetables crops.

\section{Introduction}

Soil are essential resources for food production. Heavy metal contamination of soil is of importance both in ecological and health aspects. Some of the heavy metals are known as essential microelements (e.g. Fe, Mn, Cu, and $\mathrm{Zn}$ ) while others like $\mathrm{Cd}, \mathrm{Ni}$ and $\mathrm{Pb}$ may be toxic both for plants and animals (Adriano, 1985). Extreme contamination of soils is usually the consequence of human activities. Their accumulation reduces soil fertility, soil microbial activity, and plant growth as well as the quality of agricultural products. Cadmium enters into the food chain and its weekly human intake threshold limit is $0.525 \mathrm{mg}$ Cd per capita (Bergmann, 1988). In the last decades, $C d$ is a recognized contaminant in the environment. Sources of contamination are fossil fuels, metal industry, mining, wastewater and traffic (Kloke, 1981). Thus once ecosystems are contaminat- 
ed by this hazardous element, this become potential threat for many years. Their danger can only be reduced either by dilution in the environment or by being covered or buried for example by sediment (Morgan, et al. 1986). Cadmium is mostly used for the galvanization and alloy of other metals as well as for making paints, batteries and catalyzers. Used metal fittings, rubber, plastics, tires, paints etc are materials emitting $\mathrm{Cd}$ in the environment (Adriano, 1985). Soil contaminations by heavy metals are also caused by sources of agricultural origin; sewage sludges, fertilizers, liming materials and pesticides (Adriano, 1985). Among fertilizers, phosphates are potential sources of $\mathrm{Cd}$ contamination (Adriano, 1985 and Bergmann, 1988) In soil free of contamination, soil Cd levels are determined by parent rocks. Rocks of volcanic origin usually contain less $\mathrm{Cd}$ than alluvial rocks. Cadmium is relatively immobile in soils; therefore it may accumulate in concentrations having environmental hazards (Kloke, 1980). There is no satisfactory information for plant uptake and total Cd content of soil in Bangladesh. Cadmium uptake of plants is a function of forms of $\mathrm{Cd}$ in soils. Soil properties influencing $\mathrm{Cd}$ uptake in plants are: $\mathrm{pH}$, soil organic matter, redox potential, temperature, total $\mathrm{Cd}$ content, and the presence of other soluble compounds or ions (e.g. $\mathrm{Cu}, \mathrm{Zn}$, and $\mathrm{Ni}$ ).
The aim of this study was to determine the transfer of Cd into food chain through vegetable crop uptake and its effects on plant growth and plant nutrient contents.

\section{Materials and Methods}

The soil used in the experiment belongs to the "Dhamrai series" and was collected from an agricultural field at Uthly village of Dhamrai Thana, Savar, Bangladesh. Soils were treated with $\mathrm{Cd}$ by the addition of $3 \mathrm{CdSO}_{4} \cdot 3 \mathrm{H}_{2} \mathrm{O}$ as a source of Cd. Seven $\mathrm{kg}$ soil was taken in each pot. The pots were replicated at three times for each vegetable. Total number of pots was 24 . The numbers of plants grown/pot were 6 for each vegetable and normal fertilizer dose was applied. Fresh and dry matter weights were determined after the harvest. The planting and harvest time were September 1999 and November 1999 respectively. The available nitrogen of the soil was determined by alkali distillation method using Devarda's Alloy as described by Black (Black, 1965) after extraction of the soil sample with $2 \mathrm{M} \mathrm{KCl}$ solution. The total phosphorus was determined colorometrically by developing the yellow color with vanadomolybdate after digestion of the soil with $\mathrm{HClO}_{4}: \mathrm{HNO}_{3}$ (1:5) mixture as described by Jackson (1962). Total nitrogen content of plant samples was determined by alkali distillation on the Kjeldahl digest as suggested 
by Jackson (1962). Total contents of Cd, P, K and $\mathrm{Mg}$ were determined after wet oxidation of plant sample with $\mathrm{HClO}_{4}$ : $\mathrm{HNO}_{3}$ (1:5) following Jackson et al. (1965). The test of significance of different treatment means was computed by Duncan's Multiple Range Test (DMRT) at $5 \%$ level of significance.

\section{Results and Discussion}

\section{Fresh and dry matter production}

An increase in yield of 20.8 and $21.7 \%$ were observed in lettuce and 59.5 and $38.7 \%$ in spinach fresh and dry matter production of shoot, respectively (Table I). Lal sak was found to be sensitive to Cd-toxicity with a reduction of $1.6 \%$ in fresh weight and $7.4 \%$ in dry weight and for data sak yield reduction was 38.8 and $22.9 \%$ in fresh and dry matter production, respectively. Lehoczky et al. (1997) found a maximum fresh weight reduction of $43 \%$ (at $100 \mathrm{mg} / \mathrm{l} \mathrm{Cd}$ in relation to the control plants) in corn shoot. Fresh matter production of lettuce and spinach root increased by 17.9 and $26.4 \%$ respectively while root dry matter was increased by 17.7 and $20 \%$ in these two vegetable crops. However, application of $5 \mathrm{mg} \mathrm{kg}^{-1} \mathrm{Cd}$ negatively influenced the growth of Lal and data sak root, whose fresh matter production was reduced by 18.2 and $16.5 \%$ and dry matter by 11.0 and $17.1 \%$ respectively. The results of the present investigation are in agreement 


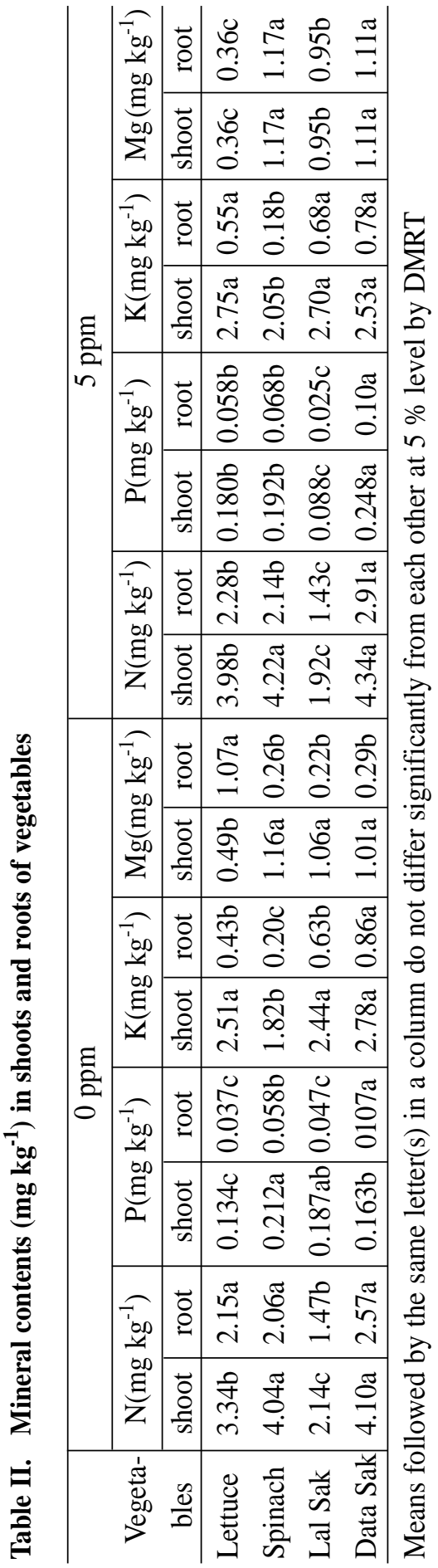

with the findings in garlic and spinach (Lehoczky et al., 1997) and in lettuce (Gracia, 1996). They observed reduced dry matter yields of plants due to higher Cd concentrations. Gerzabek and Ullah (1990) reported a depression in dry matter yield of maize due to $\mathrm{Cd}$ application. They also observed that root was less affected by $\mathrm{Cd}$ than shoots.

\section{Mineral nutrition}

Average nitrogen, phosphorus, potassium and magnesium content of lettuce, spinach, Lal sak and data sak are presented in the Table II. Treatments were statistically signif icant at $1 \%$ level. Lal sak had significantly lower concentrations of nitrogen than those of other three vegetables which did not differ from each other at control condition. The vegetables differed among themselves in the contents of nitrogen both in roots and shoots due to their differential abilities in taking up this element. However, application of Cd did not have any influence on $\mathrm{N}$ uptake (Table II). Shoot accumulated more nitrogen than that of roots indicating an unrestricted transfer of $\mathrm{N}$ from root to shoot. Cunningham (1977) found a depressive effect of Cd on N uptake in plants at higher concentration of added Cd. Application of 5 ppm Cd did not affect very much the contents of $P$ in the investigated crops except Data sak compared 
with their control. Data sak had the higher contents of $\mathrm{P}$ than that of the control probably due to the dissolution of Ca-phosphate present in the soils. From the data it is evident that higher $\mathrm{Cd}$ concentration reduces $\mathrm{P}$ concentration in spinach and in Lal sak. Krupa et al. (1999) reported similar findings in rye leaves. Results showed that most of the $\mathrm{K}$ was translocated from root to shoot, which accumulated $\mathrm{K}$ up to 12 times that of the roots. Such accumulation is due to the mobility of $\mathrm{K}$ within the plants. Similar findings were also reported in Amaranthus hypochondriacus by Jasiewiz and Antonkiewiez (1999). The contents of magnesium in the investigated crops remained unaffected by the application of $\mathrm{Cd}$ to the soil compared with the control. Similar findings were observed by several investigators Cunningham.
(1977) found depressive effect of Cd on $\mathrm{Mg}$ uptake in plants.

The transfer factor (TF) of heavy metals from soil to plant is mostly expressed as activity in plant/activity in soil. They are used as parameters for transfer models for predicting the concentration of heavy metals in foodstuffs and for estimating dose impacts on man. Soil to plant transfer factors express the relative uptake of a heavy metal element through the plant root system.

\section{TF is defined as follows}

$\mathrm{TF}=$ activity of metal in plant dry weight $/$ activity of metal in soil dry weight

The mean values of cadmium concentrations in roots and shoots of lettuce, spinach, Lal

Table III. Cadmium concentration (mg/kg) and Transfer factor (DW/DW) for lettuce, spinach, Lal sak and Data sak as affected by cadmium treatment

\begin{tabular}{l|c|c|c|c|c|c|c|c}
\hline Vegetables & \multicolumn{6}{c|}{ Cadmium level $\left(\mathrm{mg} \mathrm{kg}^{-1}\right)$} \\
\hline & \multicolumn{3}{|c|}{$0 \mathrm{mg} \mathrm{kg}^{-1}$} & \multicolumn{3}{c}{$5 \mathrm{mg} \mathrm{kg}^{-1}$} \\
\hline & \multicolumn{2}{|c|}{ Root } & \multicolumn{2}{c|}{ Shoot } & \multicolumn{3}{c}{ Root } \\
& $\begin{array}{c}\text { Conc. } \\
\left(\mathrm{mg} \mathrm{kg}^{-1}\right)\end{array}$ & $\mathrm{TF}$ & $\begin{array}{c}\text { Conc. } \\
\left(\mathrm{mg} \mathrm{kg}^{-1}\right)\end{array}$ & $\mathrm{TF}$ & $\begin{array}{c}\text { Conc. } \\
\left(\mathrm{mg} \mathrm{kg}^{-1}\right)\end{array}$ & TF & $\begin{array}{c}\text { Conc. } \\
\left(\mathrm{mg} \mathrm{kg}^{-1}\right)\end{array}$ & TF \\
\hline Lettuce & $2.50 \mathrm{a}$ & 0.76 & $0.08 \mathrm{~b}$ & 0.02 & $39.75 \mathrm{a}$ & 12.81 & $1.85 \mathrm{ab}$ & 0.52 \\
Spinach & $2.61 \mathrm{a}$ & 0.66 & $0.10 \mathrm{~b}$ & 0.03 & $22.88 \mathrm{~b}$ & 8.89 & $2.05 \mathrm{a}$ & 0.74 \\
Lal sak & $1.60 \mathrm{~b}$ & 0.52 & $0.07 \mathrm{~b}$ & 0.02 & $13.63 \mathrm{~d}$ & 3.54 & $1.20 \mathrm{~b}$ & 0.31 \\
Data sak & $1.33 \mathrm{~b}$ & 0.43 & $0.60 \mathrm{a}$ & 0.22 & $15.00 \mathrm{c}$ & 6.46 & $2.50 \mathrm{a}$ & 0.83 \\
\hline
\end{tabular}

Means followed by the same letter (s) in a column do not differ significantly from each other at $5 \%$ level by DMRT 
sak and data sak and the transfer factor for different vegetables calculated on the basis of plant dry weight are presented in Table III. The analysis of variance (ANOVA) of the data showed that results were significant at 1 $\%$ level with control treatment in shoot and 5 ppm cadmium concentrations in root.

Lettuce roots accumulated more cadmium than other vegetables at $5 \mathrm{mg} \mathrm{kg}^{-1} \mathrm{Cd}$ in soil solution. But at control treatment $\left(0 \mathrm{mg} \mathrm{kg}^{-1}\right)$ Cd was accumulated more in spinach than in other crops Roots accumulated more cadmium than shoots indicating that $\mathrm{Cd}$ was not readily translocated from root to shoot. At 5 $\mathrm{mg} \mathrm{kg}{ }^{-1} \mathrm{Cd}$, Lal sak accumulated the lowest amount of Cd followed by lettuce. Spinach and data sak had significantly higher concentrations of Cd than Lal sak. Higher accumulation of cadmium in roots of plants have been reported by many investigators in cucumber (Moreno et al., 2000), in lettuce, maize and pea plants (Harnandez et al. 1996), in maize (Gerzabek and Ullah, 1990), in lettuce and other crops (Morel et al. 1994). A similar phenomenon was found in all vegetables in the present investigation.

The investigated crops varied in their ability to absorb Cd and to transfer it to the different parts of the plants. Roots had much higher transfer factor (2 - 25 orders of magnitude) than that of shoots. Low transfer factors were found under control condition compare with those of $5 \mathrm{mg} \mathrm{kg}^{-1}$ cadmium treatment ( Table III). Results showed that Data sak had the highest transfer factor (0.22 and 0.83 ) in vegetative parts followed by spinach (0.03 to 0.74 ) indicating that the two vegetables are the good accumulator of Cd. These two crops should not be cultivated in the cadmium polluted agricultural fields. When the results of this experiment were compared with the transfer factors found by Garate et al. (1993) the values obtained here for lettuce are seen to be larger, though differences are less than an order of magnitude. Garate et al. (1993) reported 7 to 10 times higher Cd concentration in root than shoots of lettuce. Hernandez et al. (1996) found five times higher Cd concentration in plants.

\section{Conclusion}

As a consequence of the Cd contamination, dry matter production of lettuce and spinach increased while it decreased for Lal sak and data sak. The contents of $\mathrm{N}, \mathrm{P}, \mathrm{K}$ and $\mathrm{Mg}$ in all vegetables roots and shoots with increasing level of Cd shows the variations in elemental concentrations in different plants. The investigated vegetable crops had differential abilities to absorb and accumulate $\mathrm{Cd}$ in both roots and shoots.

\section{References}

Adriano, D.C. (1985) Sources, essentiality, and biogeochemical cycling of trace elements. 
New results in the research of hardly know trace elements. Proceedings of International Symposium, Budapest, Hungary.

Bergmann, W. (1988) Ernährungsstörungen bei Kulturpflanzen. VEB Gustav Fischer Verlag, Jena, Germany.

Black, C.A. (1965) Methods of soil analysis, part II, American Society of agron. Inc. Publisher, Winsconsin, USA.

Cunningham, L.M. (1977). In: D.C.Adriano (ed.) Trace elements in the terrestrial environment. Springer-Verlag New York Inc. pp. 125-126.

Garate, A. Ramos, I. Manzanares, M. and Luccna, J. J. (1993) Cadmium uptake and distribution in three cultivars of Lactuca sp. Bull. Environ. Contam. Toxicol. 50 : 709-716.

Gerzabek, M. H. and Ullah, S.M. (1990) Influence of Fulvic and Humic Acids on Cdand Ni- toxicity to Zea mays. Bodenkulter 41(2) : 115-124.

Gracia, M.E. Lopez De Sa, (1996) Effect of cadmium concentration in the nutrient solution on lettuce growth. In: Fertilizer and Environment. (Ed.) C. Rodriguez-Barrueco. Kluwen Academic Publishers. pp. 503-508.

Hernandez, L.E. Ramos, I. Carpena-Ruiz, R. Luccna, J. J. and Garate, A. (1996) Effect of cadmium on the distribution of micronutri- ents in Lactuca sp., maize and pea plants. In: Fertilizer and Environment. (Ed.) C. Rodriguez-Barrueco. Kluwen Academic Publishers. pp. 503-508.

Jackson, M.L. (1962) Soil chemical analysis, Prentice Hall Inc. Engiewood Cliffs, Newjersy, USA.

Jackson, W.A. Craig, D. and Lugo, H.M. (1965) Effects of various cations on cesium uptake from soils and clay suspension. Soil Sci. 99 : 345-353.

Jasiewiz, C. and Antonkiewicz, J. (1999). The influence of soil contamination with heavy metals on the chemical composition of amaranthus (A. hypochondriacus). Rocz. akad. Roln. Poznaniu. 310 : 39-45.

Kloke, A. (1980). Orientierungsdaten für tolerierbare Gesamtgehalte einiger Elemente in Kulturböden. Mitt. VDLUFA H. 1 : 9 - 11.

Kloke, A. (1981) Kontamination durch Schwermetalle. In : Ullmanns Encyklopadie der technischen Chemie. 4. Aufl. 502-506. Weinheim.

Krupa, Z. Siedlecka, A. and Kleczkowski, L.A. (1999) Cadmium affected level of inorganic phosphate in rye leaves influences Rubisco subunits. Acta. Physiol. Plantarum. 21(3) : 257.

Lehoczky, E. Szabados, I. and Marth, P. (1997) 
Cadmium content of plants as affected by soil cadmium concentration. In: Teressa, $\mathrm{M}$. H. and J.B. Jones (ed.) Soil and plant analysis in sustainable agriculture and environment. Micro-macroPublishing Inc. Athens, Georgia. pp. 827-839.

Morel, R. Gomez, J. Pedreno, J.N. and Mataix, J. (1994). Effects of cadmium on nutrient distribution, yield and growth of tomato grown in soil less culture. J. Plant Nutr. 17 : 953962.
Moreno-Caselles, J. Moral, R. Perez-Espinosa, A. and Perez-Murcia, M.D. (2000) Cadmium accumulation and distribution in cucumber plant. J. Plant Nutr. 23(2) : 243-250.

Morgan, J.M. Morgan, M.D. and Wiersma, J.H. (1986) Introduction to Environmental Science, 2nd Ed. W.H. Freeman and Company. pp. 226.

Received : February 13, 1997;

Accepted : August 8, 2007 